\title{
Low-Sulfide Quartz Gold Deposit Model
}

\author{
By \\ Lawrence J. Drew \\ U.S. Geological Survey \\ Reston, VA 20192
}

Deposits in this class have been widely described and given many names:

- Mesothermal gold

- $\quad$ Mother lode type

- Homestake type

- $\quad$ Low-sulfide quartz gold

- $\quad$ Gold-only deposits

- Quartz-carbonate lode gold

- $\quad$ Synorogenic gold

- $\quad$ Turbidite hosted gold

- Structurally hosted vein systems in metamorphic terranes

Recent work by Groves and others (1998) suggested that orogenic ought to be the central focus in the title describing these deposits. The unifying theme is the tectonic setting. 


\section{Characteristics of Low-Sulfide Quartz Gold Deposits}

- Gold-only deposits hosted in granite-greenstone terranes (GGT) associated with major transcurrent strike-slip faults.

- Mineralization is sporadic along these faults, yet often continuous to great depth where it does occur.

- Ore shoots can have many forms that are related to the wide variety of secondand third-order structures that can develop in (or be used by) strike-slip fault systems.

- The hydrothermal fluid is near neutral, rich in $\mathrm{CO}_{2}$, and produced by metamorphic reactions.

- Intense carbonate alteration is always present.

- Mineralization is often contemporaneous with spatially associated granitic intrusions, but not genetically related to them.

- Mineralogy of deposits is limited, in descending order, to quartz, carbonates, alkali feldspar (usually albite), sericite, pyrite, and minor amounts of tourmaline, arsenopyrite, scheelite, molybdenite. No significant base metals (copper, lead, zinc, etc.) occur. 


\section{Tectonic Control of the Occurrence of Low-Sulfide Quartz Gold Deposits}

\section{Field Examples:}

Low-sulfide quartz gold deposits are distributed near major faults (figure 1) with their locations controlled by secondary faults (Clovine and others, 1988).

The Bocono Fault Zone, Venezuela (figure 1 ), is a transcrustal fault (principal deformation zone; Colvine and others, 1988).

\section{BOCONO FAULT ZONE VENEZUELA}

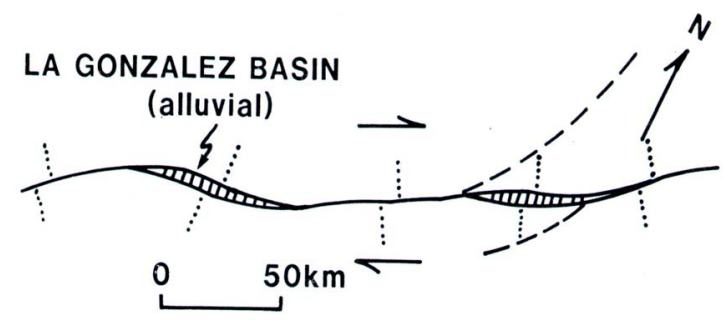

Figure 1. Geological sketch map of the Bocono Fault Zone, Venezuela. Note scale and shape of alluvial basins and their positioning relative to fault bends (after Schubert, 1980).
The Barton Bay Lithotectonic Zone, Superior Province, Canada (figure 2), is a region within the principal deformation zone that has experienced high strain within a transcrustal fault (Colvine and others, 1988).

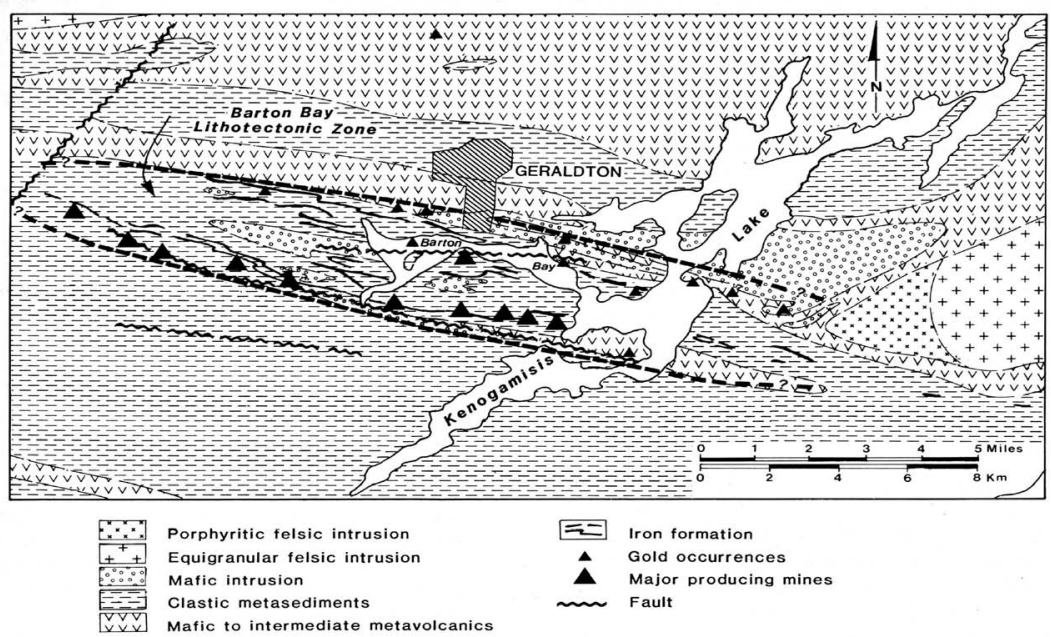

Figure 2. Distribution of gold mineralization within the Barton Bay Lithotectonic Zone in the Geraldton area, Ontario, Canada (after Macdonald, 1984). 
Low-sulfide gold deposits occur in many granite-greenstone belts in cratons around the world. As shown in figure 3 , the deposits in the Archean Yilgarn craton of Australia generally have a strong spatial association with strike-slip faults and are hosted in the greenstones and the granites. The association of the gold deposits with late granites within these terranes is probably not genetically linked to the granites themselves. Instead, the gold deposits and the granites are the product of the tectonic and thermal evolution of collisional orogens.

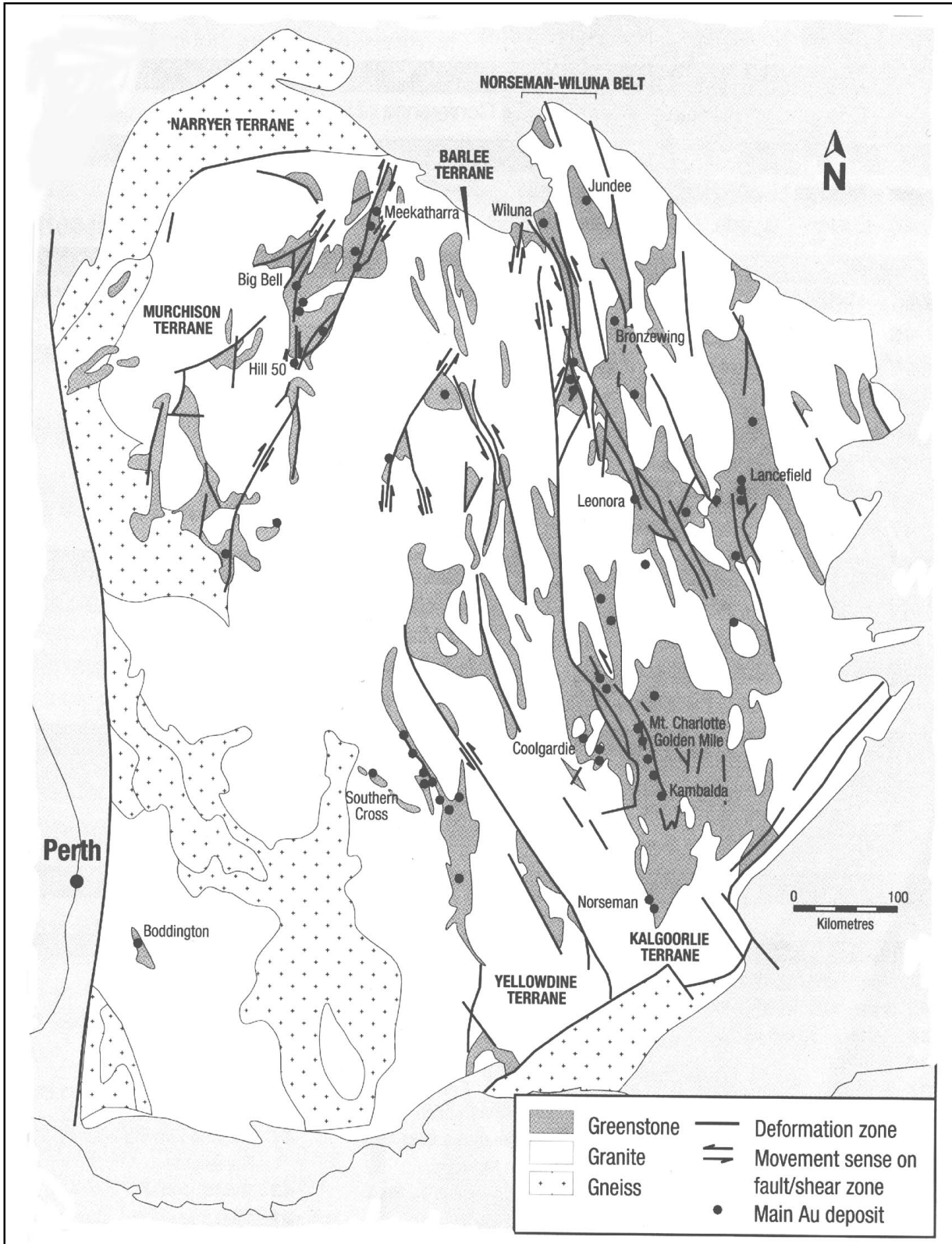

Figure 3. Map of the Yilgarn craton, Australia, showing granites/gneiss and greenstone belts with larger gold deposits (Phillips and Zhou, 1999, figure 1). 


\section{Tectonic Framework}

Low-sulfide quartz gold deposits occur in collision orogens, such as the continent-tocontinent orogen shown in figure 4 . In such an orogen, transcrustal strike-slip (and thrust) faults are large-scale strain features developed as farfield stress is accommodated during the intense shortening of the crust associated with collision. These faults provide conduits for the large volume of fluid that is generated during collision. This fluid flows into upper levels of the crust where the gold deposits are formed.

As stress is accommodated by movement along strike-slip faults (the role of thrust faults are excluded for the moment), inhomogeneities in the crust cause the tips of the faults to shift (figure 5). The zones between faults have distinct structures and are called fault duplexes or accommodation zones. Note that these fault systems can be on either side of the volcanic arc (figure 4, $5)$.

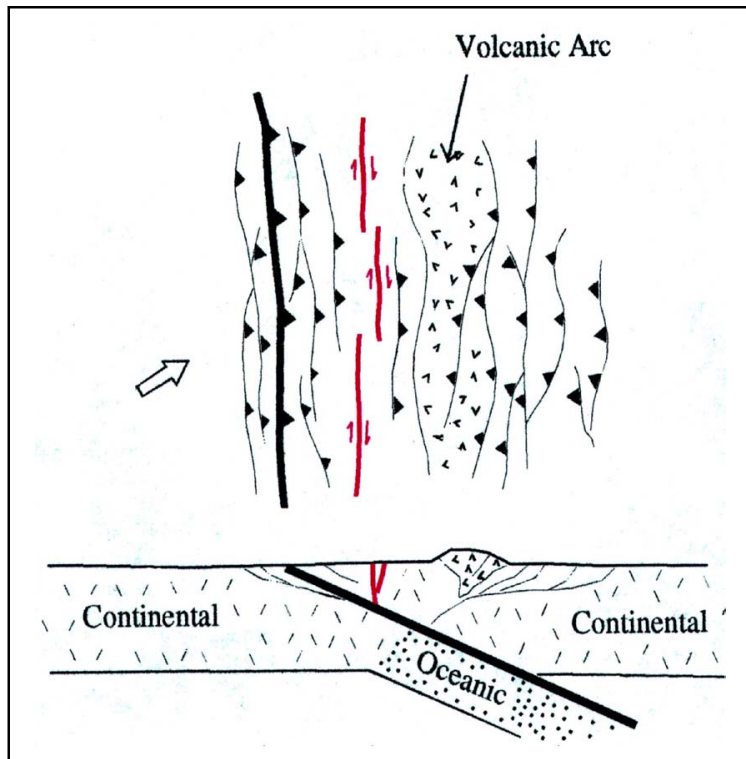

Figure 4. Alpine-Himalayan-type collisional boundaries (Bally and Oldow, 1985).

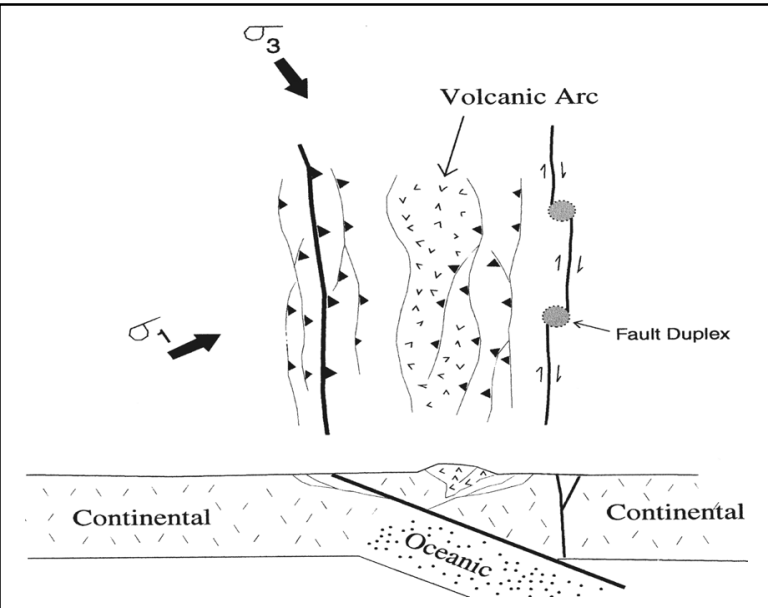

Figure 5. Alpine-Himalayan-type collisional boundaries with location of duplexes (Bally and Oldow, 1985). 
A strike-slip fault duplex is a secondary structure (strain feature) developed in the principal deformation zone of a strike-slip fault system in which stress in the far-field is transferred from the tip of one fault to the tip of another fault. The duplex shown in figure 6 is an extensional duplex in which a small sedimentary basin formed. In the deeper levels of the duplex, earthquake energy that propagates along the upper fault is absorbed, and mineral deposits may be formed.
The idealized internal structure (the tensionalshear mesh) in a extensional duplex (figure 7) was suggested by Sibson (1986) on the basis of Hill (1977). Many mineral deposits exhibit characteristics of having been deposited in a tensional-shear mesh system.

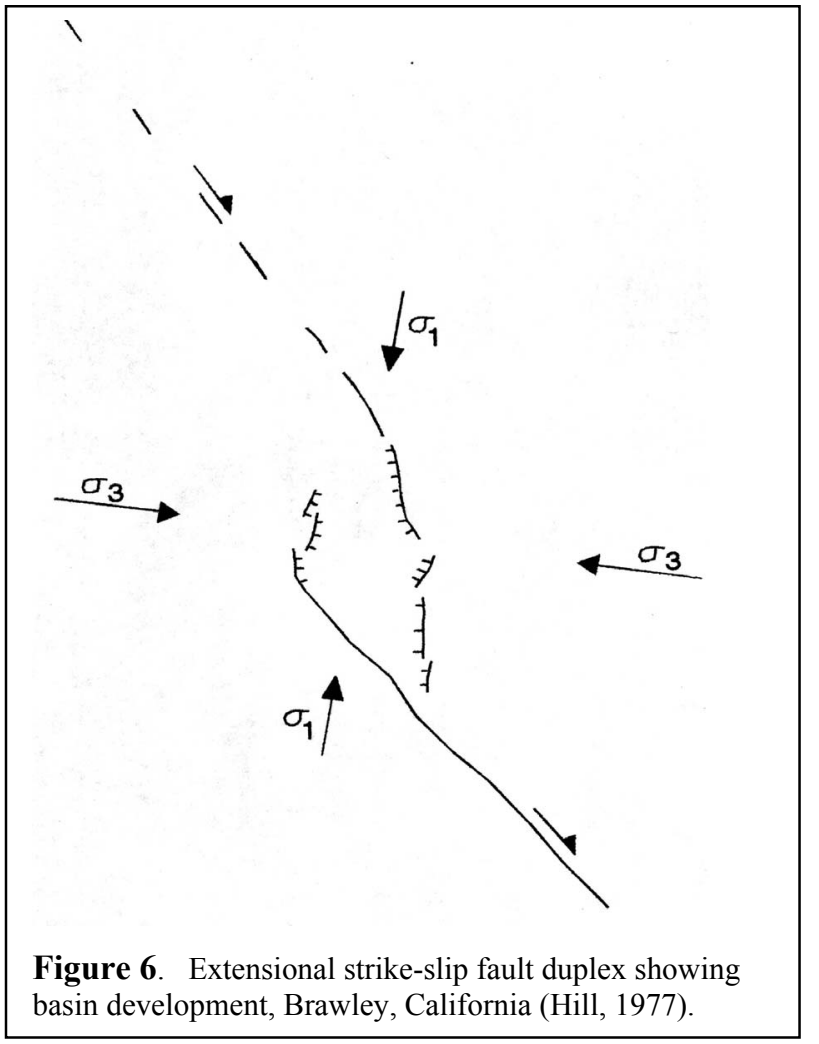

Figure 6. Extensional strike-slip fault duplex showing
basin development, Brawley, California (Hill, 1977).

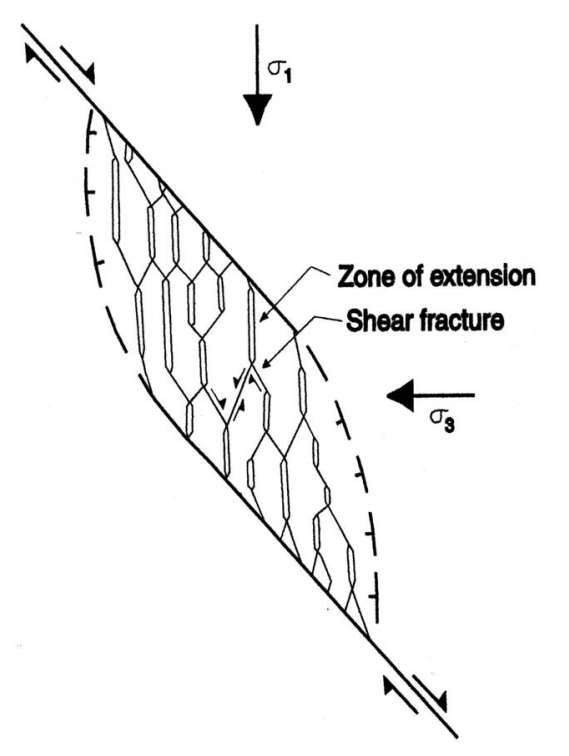

Figure 7. Idealized extensional-shear mesh system (Sibson, 1986). 


\section{Examples of Extensional Fault Duplexes}

(From Sibson, 1987, figure 1)

a. Small duplex in sandstone infilled with fibrous quartz.

b. Surface rupture trace of the 1968

Dasht-e-Bayaz earthquake, Iran.

c. Ore shoots in the Camp Bird vein system, Colorado.

d. Fault and vein system, Chuquicamata copper deposit, Chile.

e. The general mesh model consisting of linked shear and extensional fractures.

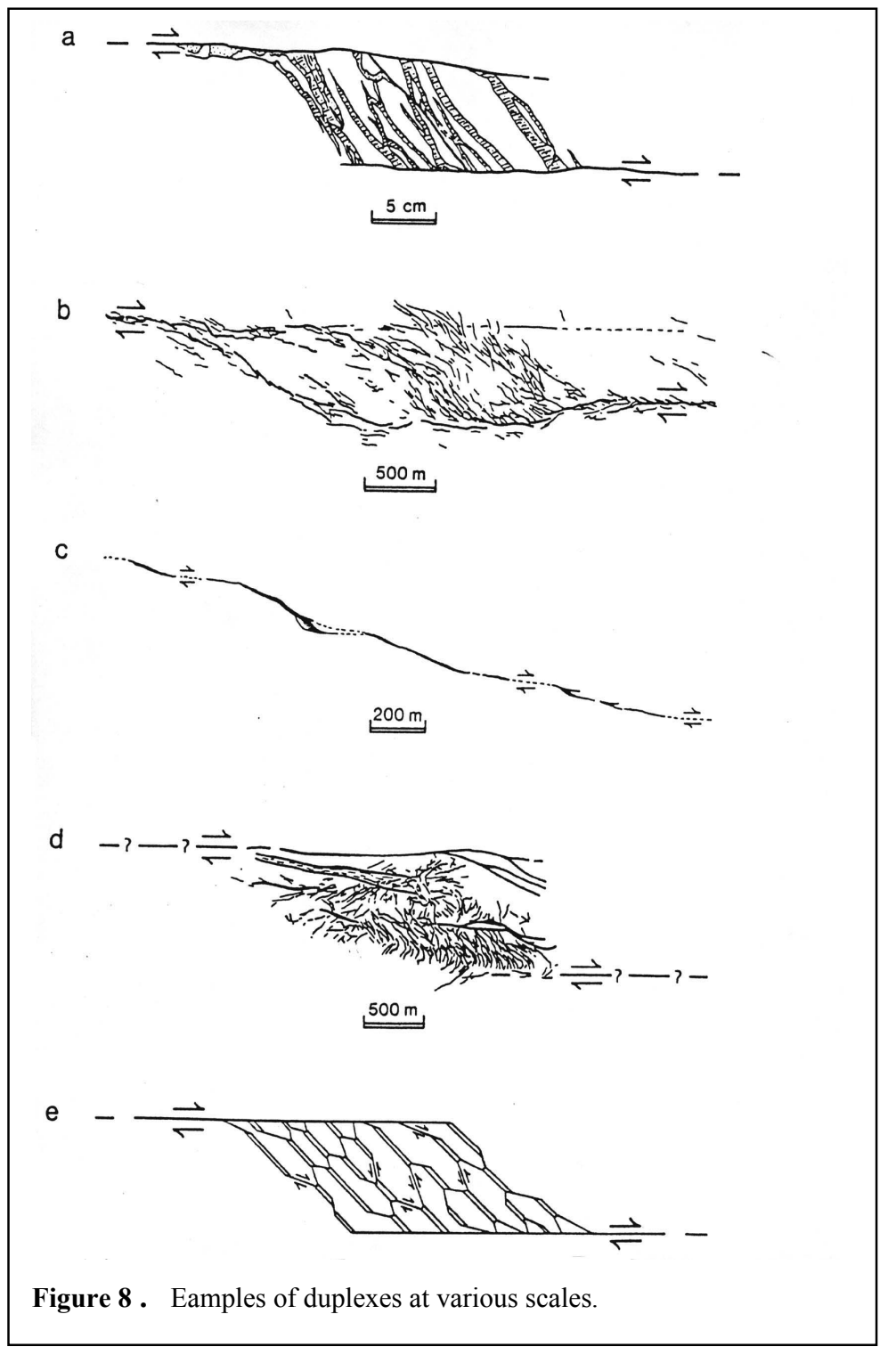



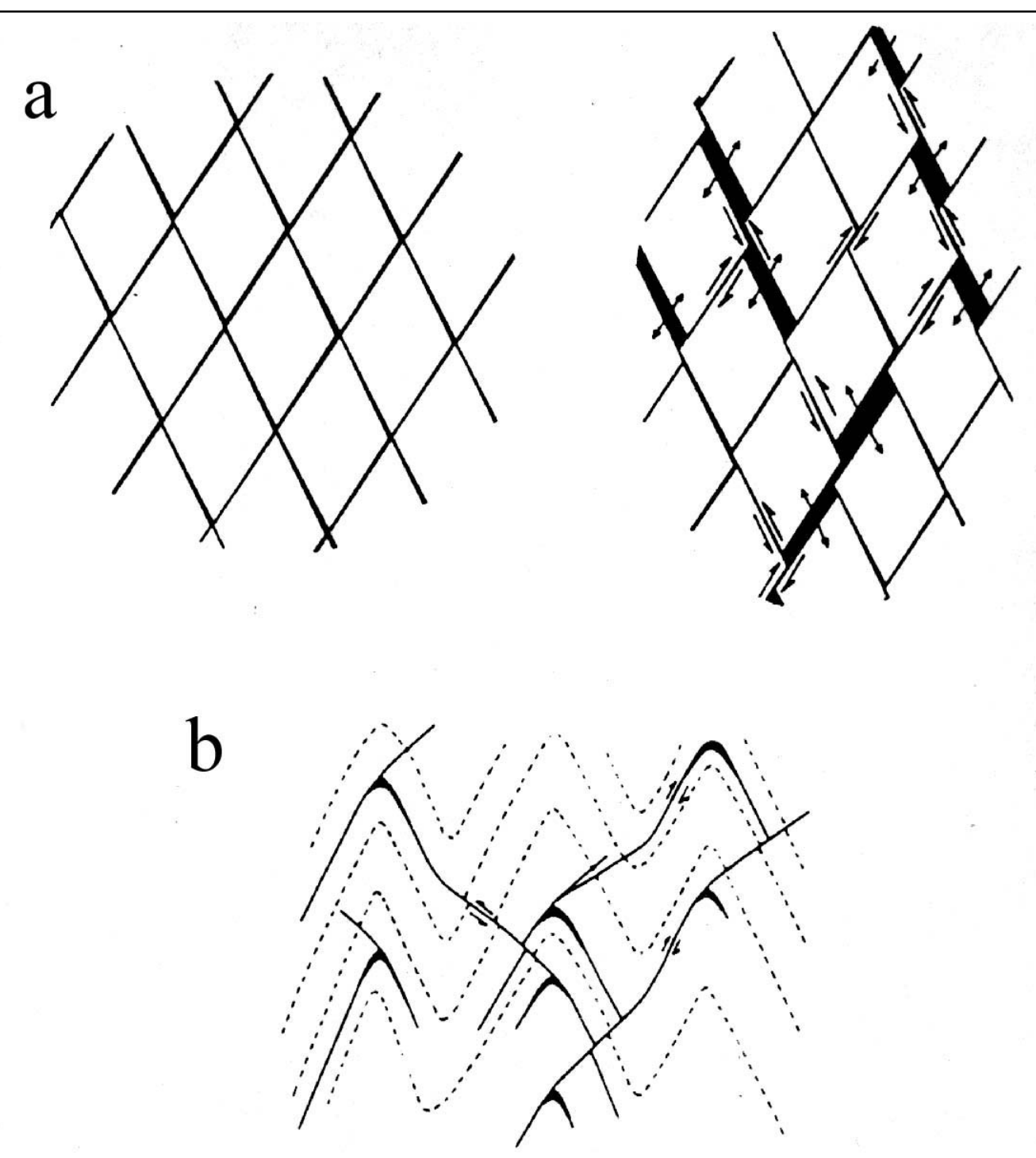

Figure 9. An example of a tensional-shear mesh (from Hodgson, 1993, fig. 20). a, Diagrammatic representation of how a complex vein system consisting of nonparallel shear veins can develop as a result of bulk, inhomogeneous flattening in which the strain is due to a combination of displacement parallel to and opening at a high angle to the length of individual shears (Hodgson, 1989); b, Pattern of intersecting limb thrusts and vein-filled dilated shear zones and fold hinges in the gold deposits of the Lachlan fold belt, Victoria, Australia (Cox et al., 1991b). 


\section{Tectonics and Structural Geology for Low-Sulfide Quartz Gold Deposits at the Scale of Deposits and Ore Shoots}

\section{Control and Distribution of Gold Mineralization}

Kerrich and Feng (1992) make the point that quartz and quartz-carbonate veins are common in metamorphic belts. The majority of these veins are from a centimeter to a meter thick and are formed locally.

In contrast, the giant quartz vein systems, tens of kilometers in length and up to 3 kilometers in depth, are hosted in brittle-ductile shear zones and are restricted to terrane boundaries. These vein systems are hosted in regional structures that cut through the lithosphere, but are usually recognized as strike-slip faults and associated duplexes along with second- and third-order splays. These veins sporadically contain gold mineralization and have extensive carbonate-alteration halos.

Hodgson (1993) stated that gold is hosted in the small-scale structures within regional deformation zones (figures 1-5).

The occurrence of economic gold mineralization in a deformation zone is often located in places where increased extension has occurred, such as in pull-apart basins (figures 1-3, 6, 7).

Deposits occur where:

1. Strain has been anomalously high and brittle and ductile features are found.

2. Preexisting structural anisotropies [for example, bedding planes (figure 8b)] exist.

3. Packages of rock with strong competency contrasts occur. For example, felsic intrusive rocks host mineralization, whereas the surrounding sedimentary rocks do not.

4. Fold limbs and noses are permeable zones (figure $8 b$ ).

Yet, a striking feature of these deposits is their great vertical continuity [in a variety of structures (figure 10)]. For example, mineralization in the Kolar gold field in India is vertically continuous to $3.2 \mathrm{~km}$. 


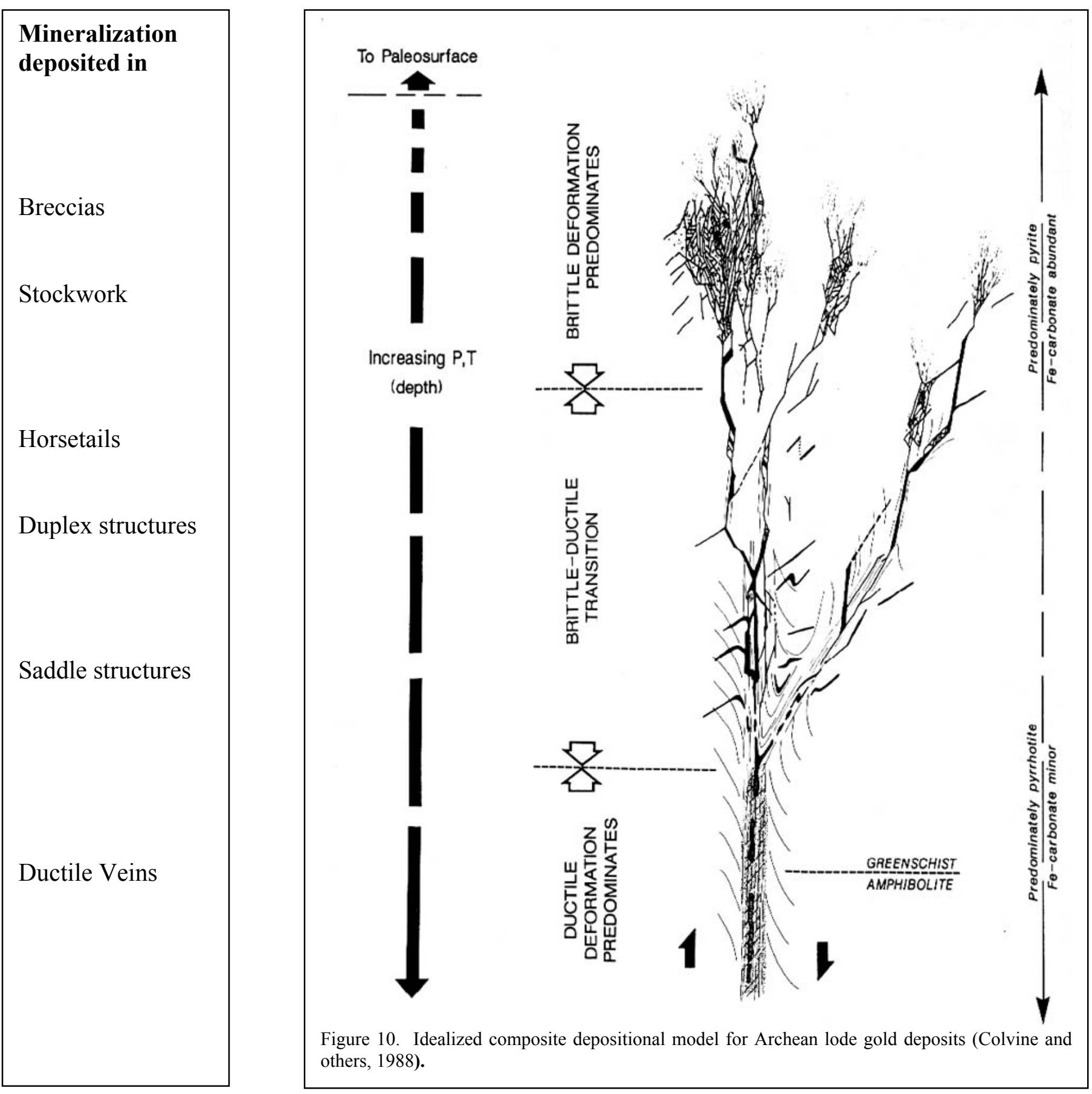




\section{Flower Structures}

Flower structures are very common strain features that develop in the principal deformation zone of a strike-slip fault. (Notice the similarity in the cross section of the flower structures and the cross section depicted in the general model for the low-sulfide quartz gold model developed by Colvine (1988, figure 10).

A

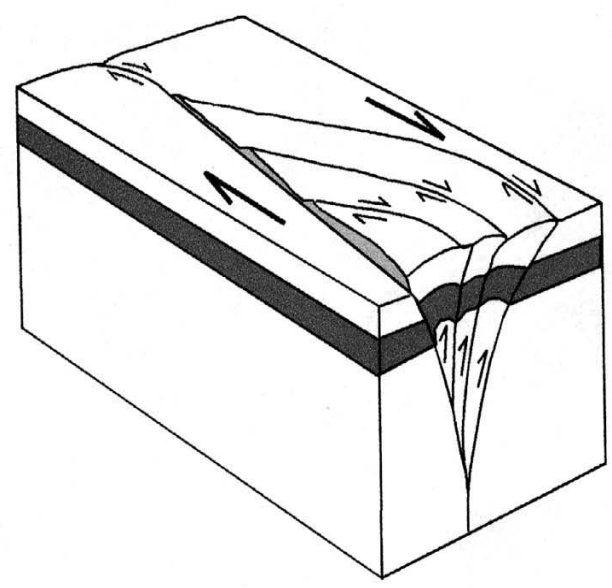

B

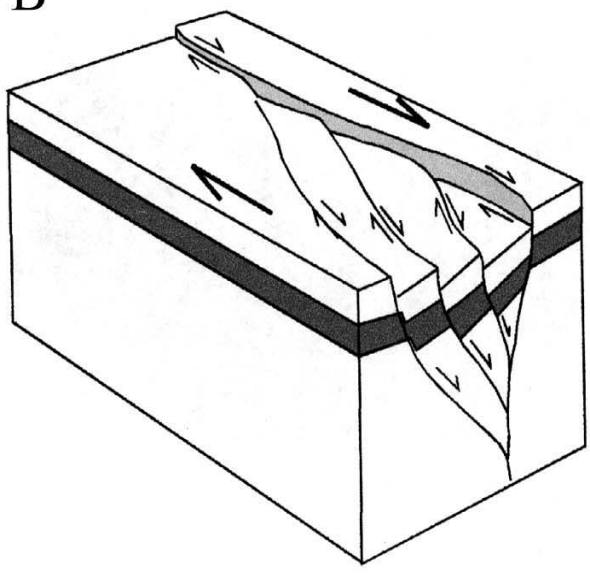

Figure 11. Block diagram of positive (A) and negative (B) flower structures. 
Figure 12 shows, in plan view, a variety of structures in the principal deformation zone of a strike-slip fault. The location of several of the individual structures - the extensional fault duplex (figures 5 and 6) with its extensional-shear mesh system (figure 7) and a negative flower structure (figure 11B) - are shown. In light of the summary by Kerrich and Feng (1992), examination of the variety of structures shown in figure 12 will help explain the occurrence of gold mineralization along a principal deformation zone of a strike-slip fault.

The giant quartz vein systems with lateral extents of tens of kilometers and up to 3 kilometers in depth are hosted in brittle-ductile shear zones and are restricted to terrane boundaries. These are regional structures that cut through the lithosphere, but are usually recognized at strike-slip fault, duplexes, and second and third order splays at mid-crustal levels. These veins sporadically contain gold mineralization.

This sporadic occurrence of gold deposits in these fault systems is caused, at least in part, by the transport and trapping mechanisms available in various segments of these faults.
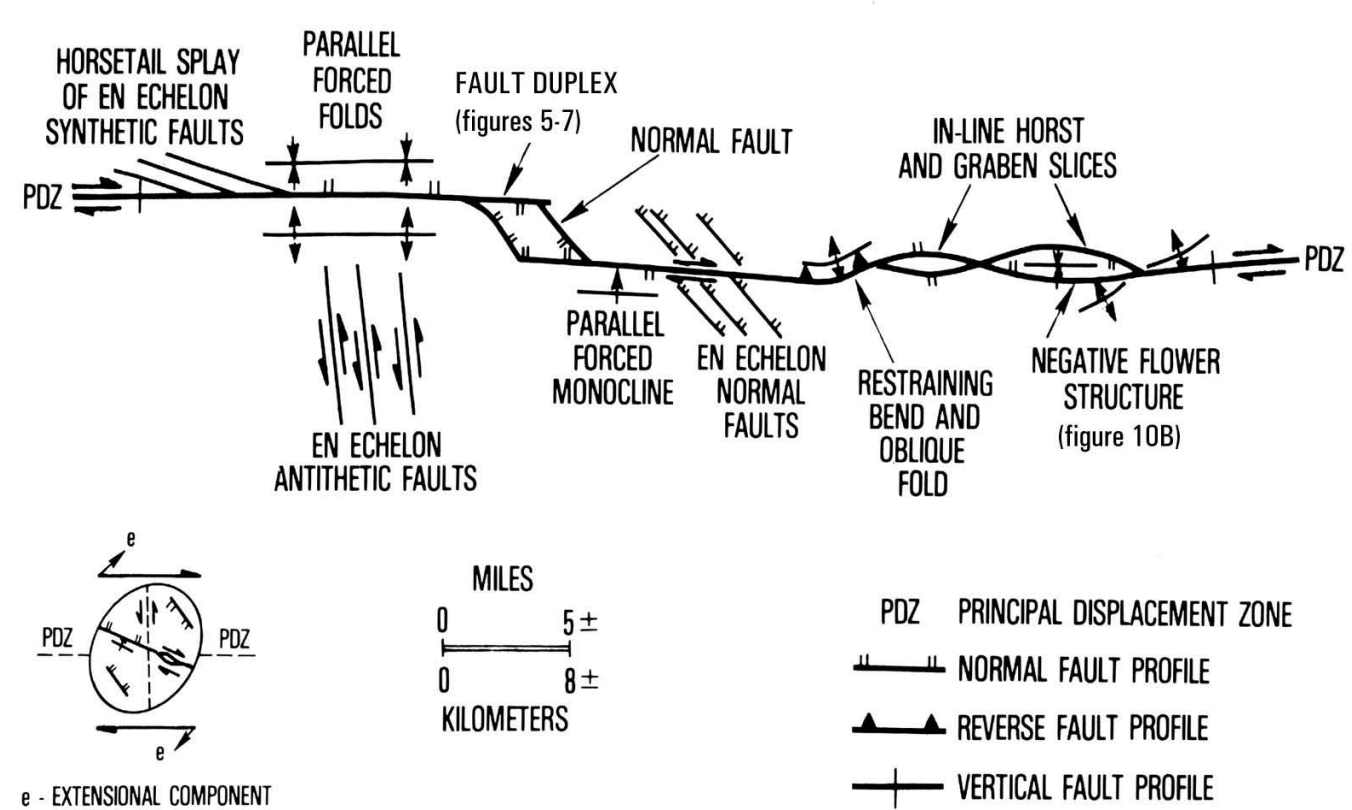

e - EXTENSIONAL COMPONENT

Figure 12. Collection of structures associated with a transtensional strike-slip fault system (from Harding, Vierbuchen, and Christie-Blick, 1985, figure 1) 


\section{Source of the Hydrothermal Fluid Associated With Low-Sulfide Quartz Gold Deposits}

\section{Framework}

Low-sulfide quartz gold deposits form as a consequence of the events that occur in the crust at the end of arc-to-continent and continent-to-continent collisions. The critical factor in these events is that hydrated rocks are subducted and (or) otherwise brought into zones where they are subjected to high geothermal gradients and dehydration reactions.

Lindgren (1895) recognized that carbonate alteration of the wallrock was a key to the genetic understanding of these deposits. Many scientists have argued that the evidence indicates that gold mineralization is associated with the introduction of large volumes of fluid into a depositional environment along structurally induced, permeable channelways. This fluid appears to be of a common composition-low salinity, aqueous, high $\mathrm{CO}_{2}$, and temperature at deposition of approximately 350 degrees. The depth of deposition ranges from 4 to $12 \mathrm{~km}$ (Böhlke, 1999). The gold is transported by the reduced sulfur complex AuHS( $\left.\mathrm{H}_{2} \mathrm{~S}\right)_{3}$ (Loucks and Mavrogenes, 1999). 


\section{The Processes of Thickening the Crust Required to Generate the Metamorphic Reactions to Form the Large Volume of Aqueous Fluid Associated With Low- Sulfide Quartz Gold Deposits}

Hodgson (1993) cited a body of evidence developed by Goldfarb and others (1986), Hamilton (1988), Hoffman (1990), and Kerrich and Wyman (1990) in which formation of low-sulfide quartz gold deposits are associated the prograding of arc-trench complexes at convegent plate margins. The model developed for the process of progradation of arc-trench complexes explains the origin of the large volume of fluid required for the formation of these deposits (metamorphic dehydration of cold oceanic sediments and island arc crust, and the origin of the felsic magmas that also intrude the major transcrustal faults which exist in these complexes).

\section{Stage 1}

Convergent plate margin collision by B-type (ocean-type) subduction as shown in figure 13.

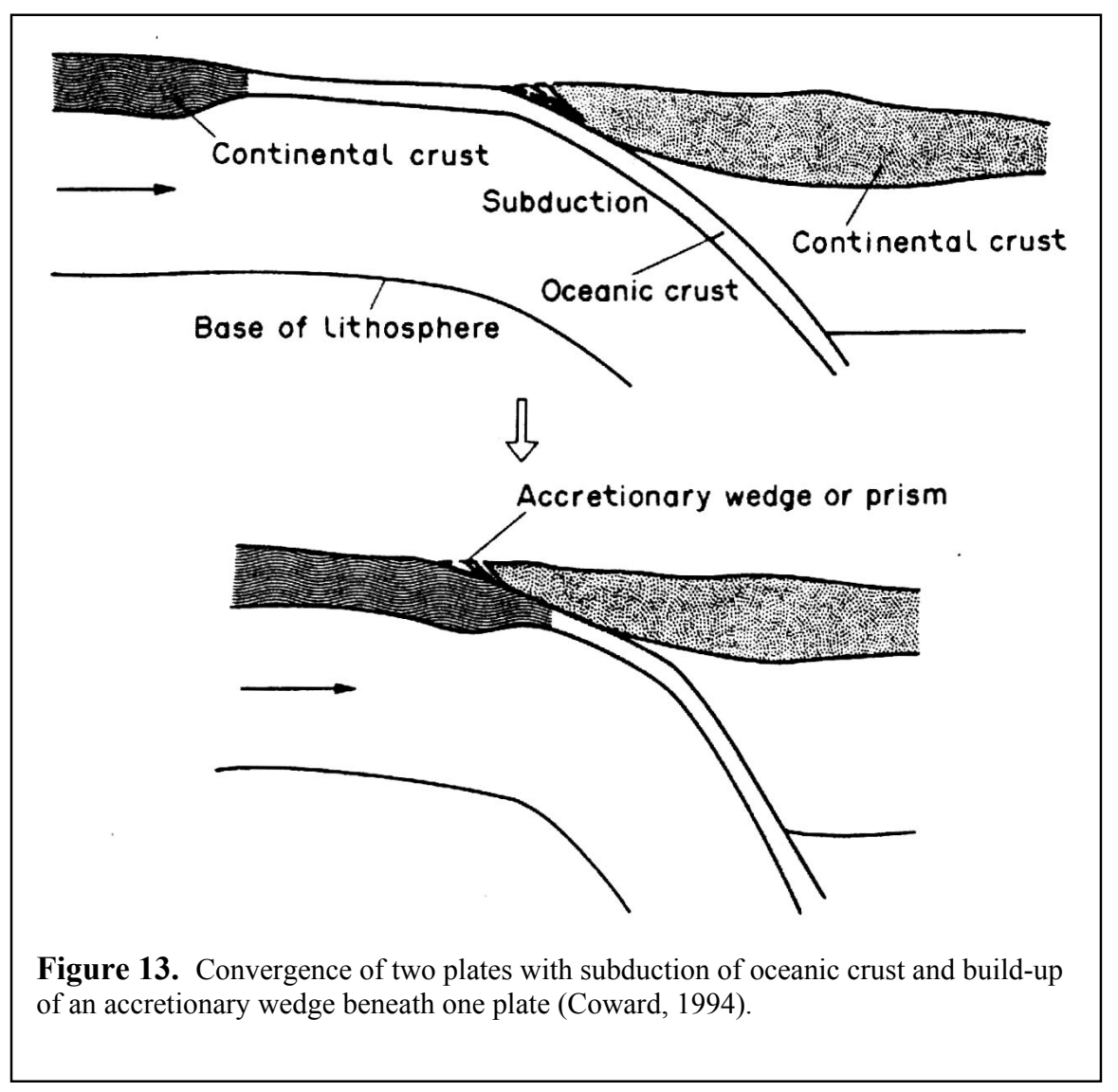




\section{Stage 2}

When two continents collide, one will try to override the other (figure 13a; Bird, 1978), and some crust may be subducted into the asthenosphyric mantle (the end of B-type subduction and the beginning of A-type (i.e., continental) subduction; Coward, 1994).

The driving force for the subduction of crust (dark plate in figure 14a) is considered to be the higher density of the crust compared with that of the accretionary prism. The density of the edge of this continent is higher because it contains basaltic dikes and sills introduced during a previous stage of rifting (Le Pichon and others, 1982).

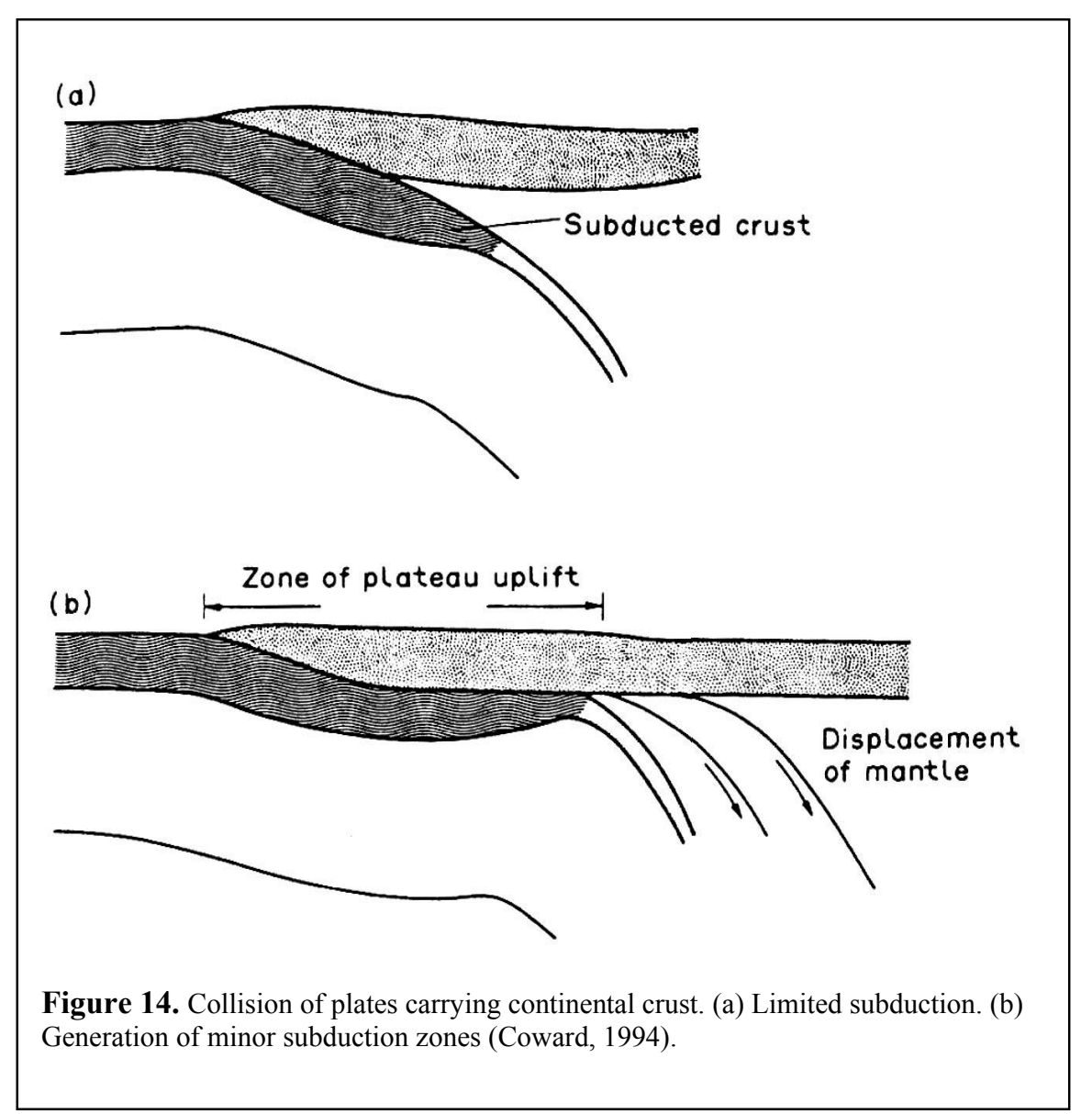

As plate motion continues, either the overriding or the overridden plate may break and stack up crustal-scale thrust sheets (figure 15; Coward, 1994). In some collision orogens, largescale thrusting verges away from the suture, thereby creating a symmetric stack of crustal-scale thrust sheets. [Such a symmetric stack is shown in the summary below in figures 18 and 19 for a hypothetical collision orogen that has generated various types of hydrothermal fluids (Kerrich and Feng, 1992)].
Figure 14. Collision of plates carrying continental crust. (a) Limited subduction. (b) Generation of minor subduction zones (Coward, 1994).
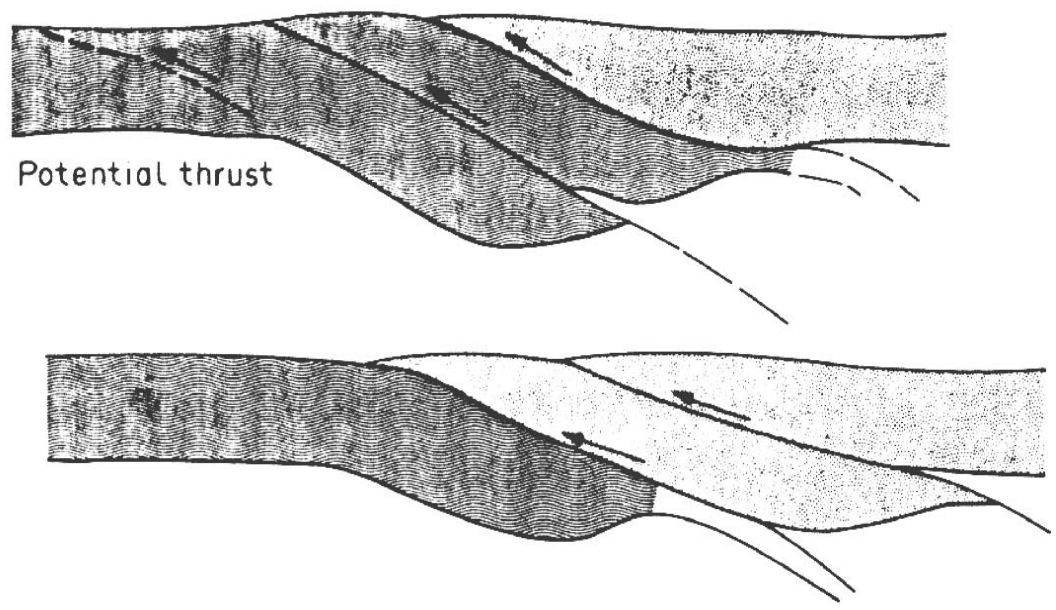

Figure 15. The development of new crustal-scale thrust sheets in the footwall (top) or hangingwall (bottom) of the main suture (Coward, 1994). 


\section{Metamorphic Fluids}

1. Low-grade metamorphic reactions produce a large volume of $\mathrm{H}_{2} \mathrm{O}$.

2. Ambient fluids produced in zones of granulitization or anatexis are $\mathrm{CO}_{2}$ rich regardless of the rock type.

3. Carbon isotope data suggest that the $\mathrm{CO}_{2}$ did not come volumetrically from the calcite precipitated during diagenesis, but rather from a source external to the rocks in which the deposits were formed; that is, the most probable source of $\mathrm{CO}_{2}$ is from a zone of granulitzation.

\section{Characteristics of Regional Alteration}

- Zones of intense alteration are sporadic within regional deformation zones.

- Carbonatization, mostly as replacement by magnesite or ankerite-dolomite-calcite, is restricted in deformation zones and is the common alteration at the deposit, as well as regional scale.

- Sulfidation, silicification, oxidation, and potassic metasomatism are characteristic but usually restricted to the deposit areas.

- Alteration is most obvious when it occurs within low-grade rocks.

- A progression from calcite to Fe-carbonate can often be observed toward the deposit.

- Chlorite is an important alteration product when the wall rock is mafic.

- Fe-sulfide (commonly as pyrite) is ubiquitous.

- Silicification (an increase in modal quartz) is often associated with the deposits.

- Many other alteration minerals, including diopside, anhydrite, Ti-minerals, tourmaline, scheelite and others, can occur.

\section{Geochemistry of Alteration}

- Most gold deposits record the massive introduction of $\mathrm{CO}_{2}, \mathrm{~K}_{2} \mathrm{O}$, S, and $\mathrm{H}_{2} \mathrm{O}$. Increases in the other components ( $\mathrm{As}, \mathrm{Sb}, \mathrm{W}, \mathrm{Mo}, \mathrm{B}, \mathrm{Ag}, \mathrm{Li}, \mathrm{Ba}, \ldots .$.$) can occur but$ not as consistent. 


\section{Timing of Mineralization}

Evidence from many deposits suggests a close temporal relation among peak deformation, metamorphism, alteration, and the introduction of gold.

1. Alteration is associated with linear zones of intense deformation and is sporadic within these deformation zones.

2. Alteration includes a regional, as well as a local, association with carbonates.

3. This empirical evidence suggests that gold was introduced into sheared and folded structures in a single event that occurred at about the same times as emplacement of granite plutons.

4. A close temporal link has been established between prograde metamorphic devolatilization and the production of low-sulfide quartz gold hydrothermal fluid [e.g., along a segment of the northwestern Alps (Pettke and others, 1999)].

\section{Mineralogy of Gold}

The main minerals of the gold-bearing zones of these deposits are quartz, carbonates, alkali feldspar (most commonly albite), sericite, pyrite, tourmaline, arsenopyrite, scheelite, and molybdenite. Pyrrhotite is common in the deep parts of deposits, as well as in deposits hosted in banded iron formation. Arsenopyrite seems to be common in deposits hosted in sedimentary rocks (Robert, 1990).

The concentration of gold may be considered to be a product of the alteration process, as well as the concentrations of B, W, Sb, Te, Mo, and As.

Although gold in quartz veins is the most distinctive occurrence, the gold in some deposits is also or largely in the altered wallrock. 


\section{Ridge Subduction}

\section{Another Model for Introducing Sufficient Heat Into the Crust to Produce the Metamorphic Reactions Required to Produce Low-Sulfide Quartz Gold Deposits}

Haeussler and others (1995) stated that the fundamental requirement for generation of low-sulfide quartz gold deposits is a heat source. Ridge subduction (figure 16) and associated processes can provide the heat necessary for the mobilization of gold. During ridge subduction, a slab window opens, and the hot asthenospheric mantle is brought into contact with the base of the cold and wet accretionary prism (figure 17). The basic requirements to generate the hydrothermal fluid associated with low-sulfide quartz gold deposits are satisfied by the configuration of tectonic and lithologic elements shown in figures 16 and 17; that is, the production of a large volume of near-neutral fluid rich in $\mathrm{CO}_{2}$ produced by metamorphic reactions in the vicinity of transcrustal strike-slip faults.

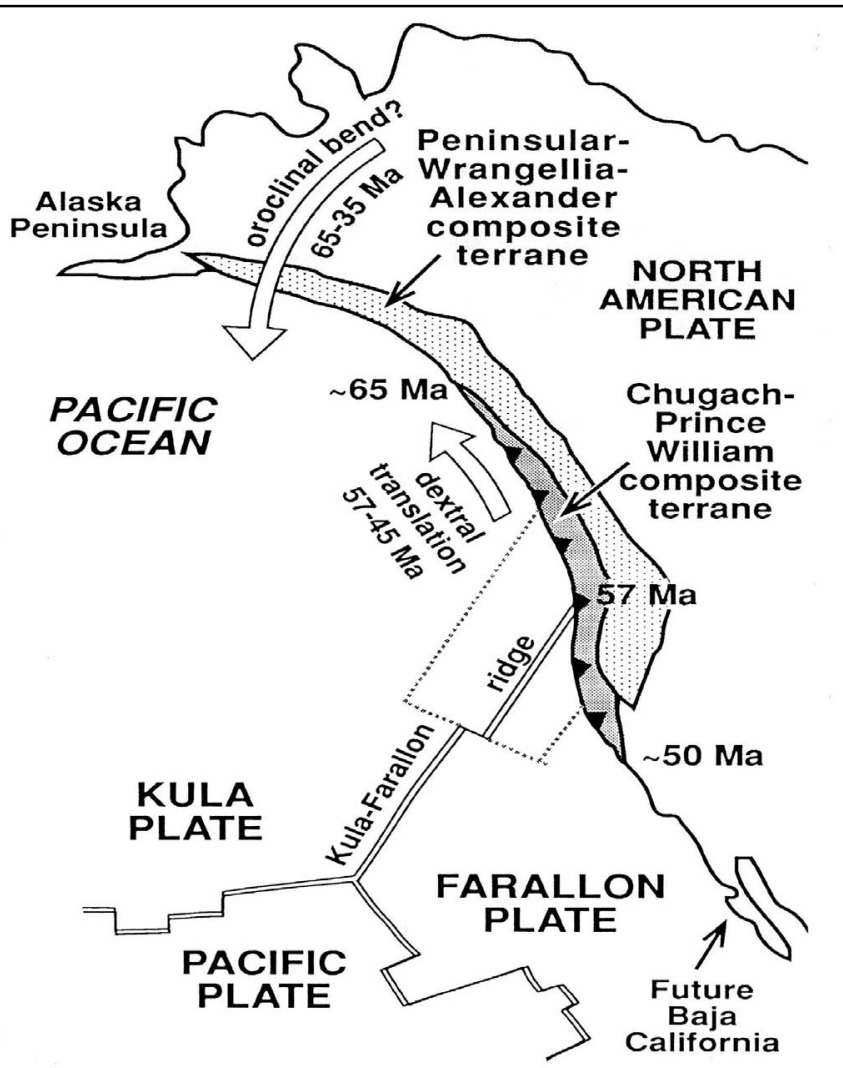

Figure 16. Early Tertiary plate reconstruction of the North Pacific. The triple junction has migrated southward between 65 and $50 \mathrm{Ma}$. The position at $57 \mathrm{Ma}$ is shown (Bradley and others, 1993).

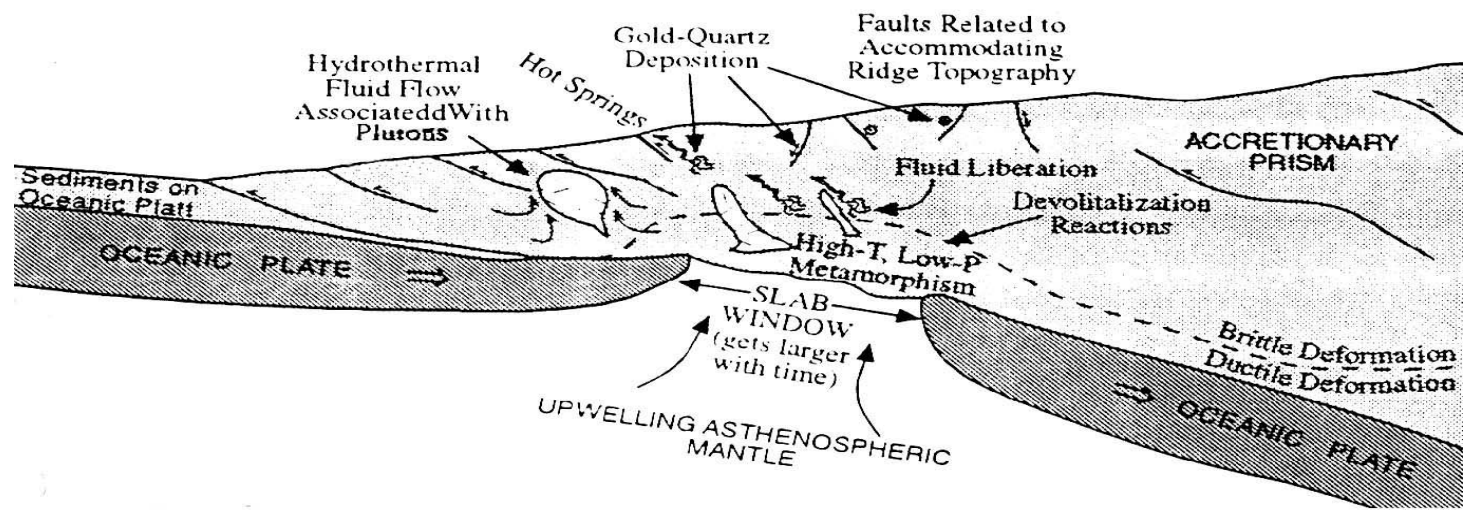

Figure 17. Cross section of a slab window created by ridge subduction with various types of gold mineralization (modified from Haeussler and others, 1995). 


\section{Summary}

Low-sulfide quartz gold deposits of all ages constitute a coherent group in terms of geological characteristics, chemistry of ore-fluids, and occurrence in accretionary tectonic environments (Hodgson 1993). The origin of these deposits must be linked to convergent margin processes accompanying the generation of major volumes of syn- to post-tectonic felsic intrusions. These felsic intrusions represent a magmatic event that has prograded over a deformed accreted complex. The genesis of the ore fluids is more complex than a simple dewatering of oceanic crust and sediments. The evidence points toward deposit formation late in the evolution of a convergent continental margin. The origin of the fluid is complex - from the evidence, we can conclude that the ore fluid is a product of deep crustal prograde metamorphism in thermally equilibrating over thicken crustal sections in which significant amounts of heat have been added incrementally by superimposed magmatism. In this reaction-invariant environment, fluid with a limited range of $\mathrm{CO}_{2}-$ to- $\mathrm{H}_{2} \mathrm{O}$ ratios, as seen in fluid inclusions, would be derived. Input of $\mathrm{CO}_{2}$ from the mantle is not necessary, and the field data speaks against this idea. The deposits are associated with deep transcrustal faults that are characterized by carbonation, thus implying that the primary fluid reservoirs are deep and large. 


\section{Hypothetical Collision Orogen With Its Fluid Budget}

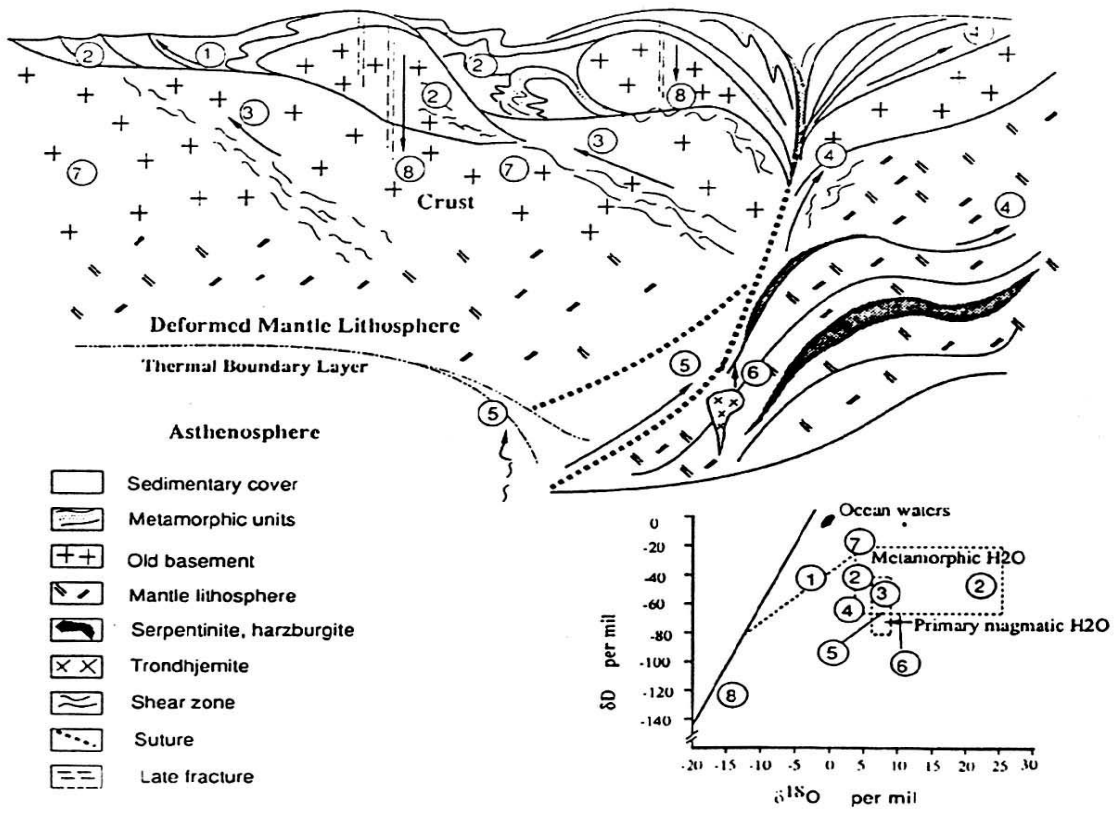

Figure 18 Fluid budget in a hypothetical collisional orogen (Kerrich and Feng, 1992). 1. Formational brines tectonically expelled from cover; 2. Metamorphic fluids; 3. Fluids from deep basement; 4. Dehydration of serpentinized harzbergite and subcreted oceanic lithosphere and sediments; 5 . Volatiles from metasomatized mantle; 6 . Magmatic fluids from granitoids; 7. Deep penetrating, isotopically evolved meteoric water; 8 . Meteoric water penetrating mountain belt following collision. Fluid events are not necessarily contemporaneous. Giant vein systems form in splays of suture for fluid reservoir 4, at midcrustal levels ( after Kyser and Kerrich, 1990).

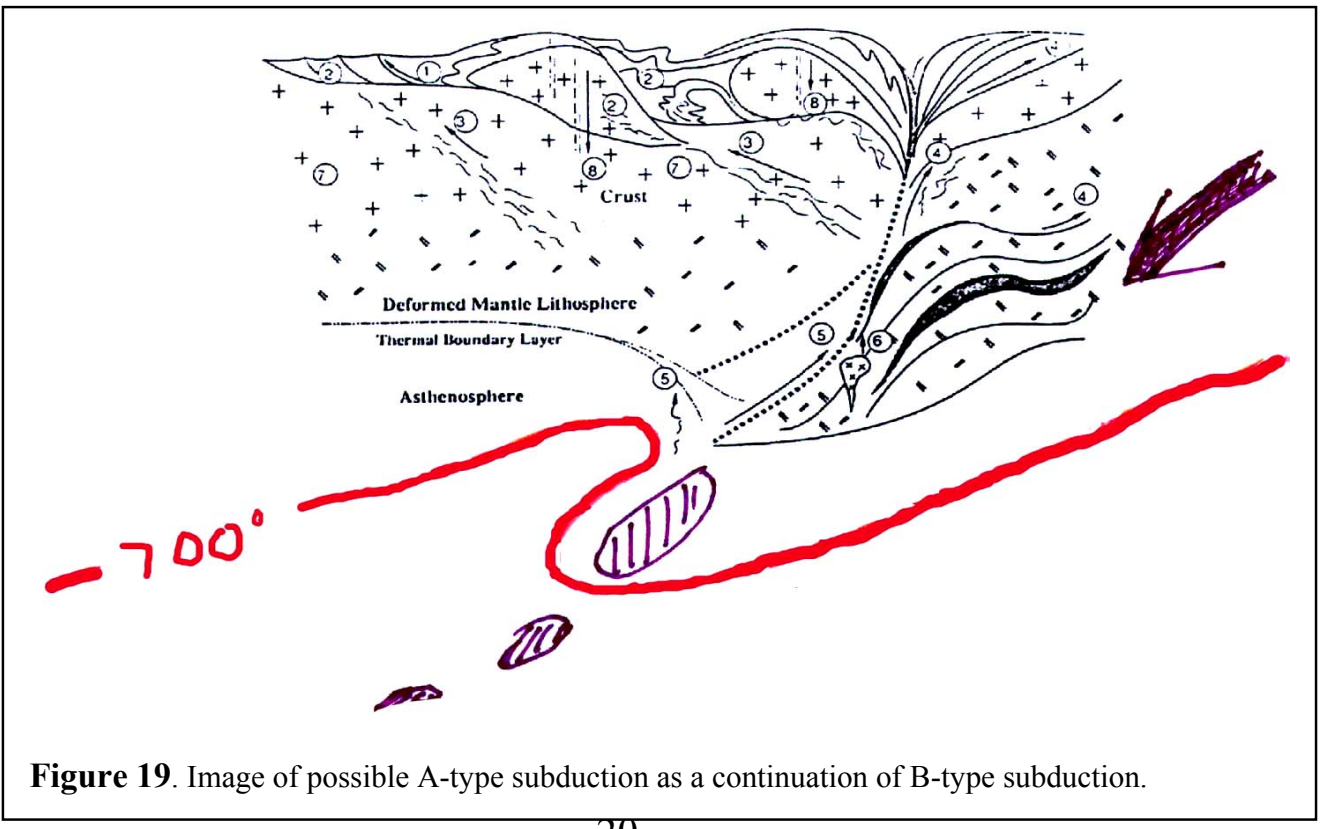




\section{The Granite-Greenstone Terrane}

Low-sulfide quartz gold deposits are hosted predominately in greenshist facies rocks and in spatial association with granites. These plutons are often undeformed implying their late emplacement in the deformation zones. Other plutons in the deformations zones are highly sheared. Syn- to late tectonic intrusions form less than $5 \%$ of the surface of belts yet host $25 \%$ of the gold mineralization. Syn- to late dioritic to trondhjmitic intrusive rocks do not show such a preference for gold mineralization. In addition, there appears to be a general trend in goldhosting plutons from quartz-bearing to silicaundersaturated lithologies.

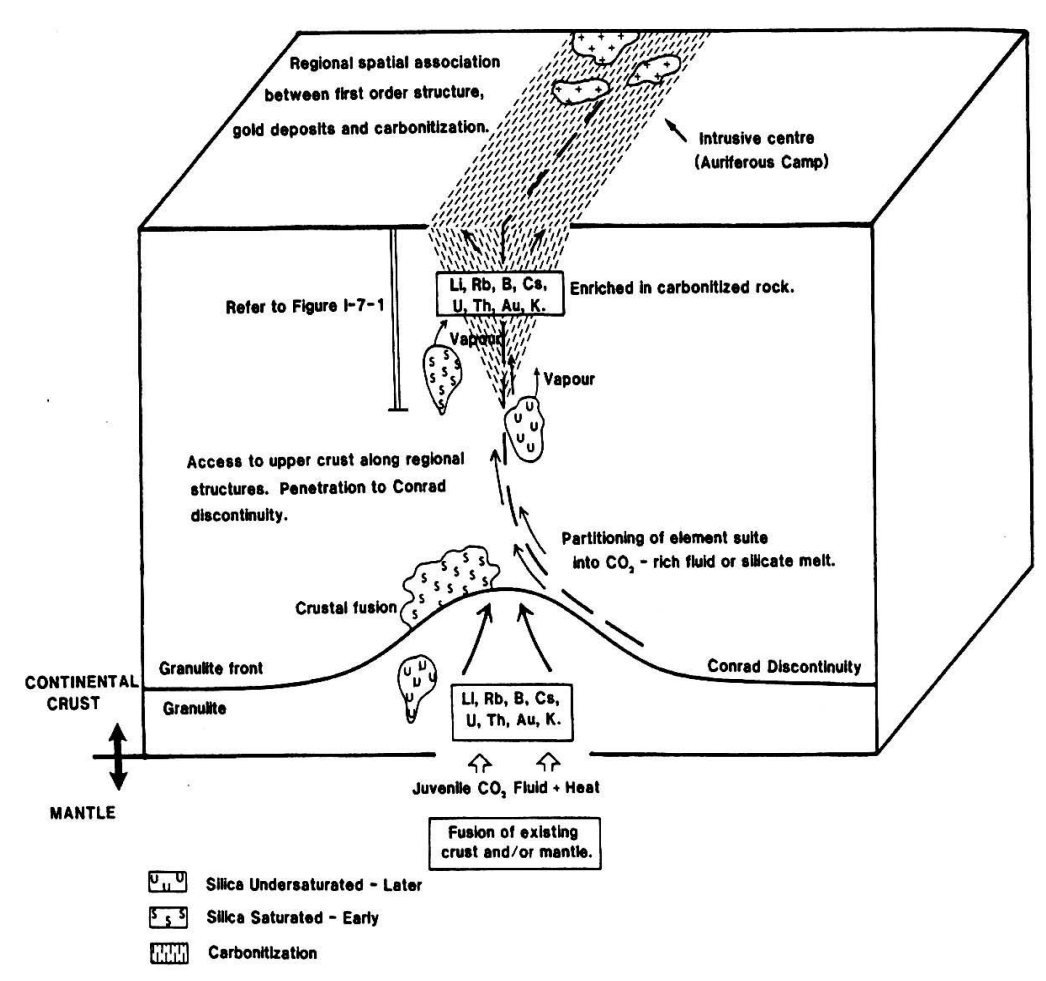

Figure 20. Composite crustal section illustrating the elements of a genetic Archean gold model. The indicated surface represents an erosion level, as observed presently. It is not intended that the Archean auriferous hydrothermal system debouched on to the surface. The vertical scale is not defined. Crustal cratonization culminates with the addition of mafic magma to the base of and into existing lower crust. Crustal thickening is accomplished in part by the addition of diapiric mass to the base of the crust, which grows downward to form a subcontinental keel. Granulitization of the lower crust results from the introduction of magma, heat and volatiles, principally $\mathrm{CO}_{2}$. A compositional spectrum of silicate magmas, from silica saturated to undersaturated, is generated by partial melting of upper mantle and lower crust, in the presence of fluids having varying $\mathrm{CO}_{2} / \mathrm{H}_{2} \mathrm{O}$ ratios. Fluids may originate by exolution from silicate magmas anywhere between the upper mantle and upper crust, and may evolve compositionally as a result of reaction with rock (granulitization) and immiscible separation. Chemical mass transfer from the mantle, lower and middle crust to the upper crust is effected by silicate magma and fluids, which migrate along zones of crustal weakness (regional structures which penetrate at least to the Conrad discontinuity). Gold concentration in the upper crust is a consequence of this late crustal magmatic, tectonic, and thermal history.

Citing the work of Wyman and Kerrich (1988) and Harttori and Hart (1990) Hodgson (1993) stated that the felsic intrusions found in regional deformation zones are derived from lower crustal and mantle sources, thereby implying that these deformation zones extend to at least the base of the crust. Recent age dating in Precambrian granitegreenstone terranes shows that the gold mineralization is from 50 to $100 \mathrm{Ma}$ younger than the nearby or hosting granitic stocks. Goldfarb and others (1998), however, found the age of the gold mineralization in the western Pacific Rim to be roughly contemporaneous with the age of the granitic stocks. 


\section{Bibliography}

Bally, A.W., and Oldow, J.S., 1985, Plate tectonics, structural styles and the evolution of sedimentary basins: American Association of Petroleum Geologists, Golden, Colorado, August 8-10, 1985, Short Course Notes, 238 p.

Bird, P., 1978, Initiation of intracontinental subduction in the Himalaya, Journal of Grophysical Research, v. 83, p. 4975-4987.

Böhlke, J.K., 1999, California gold: Geological Society of America Special Paper 338, p. 42-67.

Bradley, D.C., Haeussler, P.J., and Kusky, T.M., 1992, Timing of early tertiary ridge subduction in southern Alaska: U.S. Geological Survey Bulletin 2068, p. 163-177.

Colvine, A.C., Fyon, J.A., Heather, K.K., Soussan Marmont, P.M., Smith, P.M., and Troop, D.G., 1988, Archean lode gold deposits in Ontario: Ontario Geological Survey Miscellaneous Paper 139, 136 p.

Coward, M., 1994, Continental collision, in P.L. Hancock, ed., Continental deformation: New York, Pergamon Press, p. 264-288.

Goldfarb, R.J., Leach, D.L., Pickthorn, W.J., and Paterson, C.J., 1986, Origin of lode gold deposits of the Juneau gold belt, southeastern Alaska: Geology, v. 16, p. 440-443.

Goldfarb, R.J., Phillips, G.N., and Nokleberg, W.J., 1998, Tectonic setting of synorogenic gold deposits of the Pacific Rim: Ore Geology Reviews, v. 13, p.185-217.

Groves, D.I., Goldfarb, R.J., Gebre-Mariam, M., Hagemann, S.G., and Robert, F., 1998, Orogenic gold deposit-A proposed classification in the context of their crustal distribution and relationship to other gold deposit types: Ore Geology Reviews, v. 13, p. 7-27.

Haeussler, P.J., Bradley, D., Goldfarb, R., Snee, L., and Taylor, C., 1995, Link between ridge subduction and gold mineralization in southern Alaska: Geology, v. 23, no. 11, p. 995-998.

Hamilton, W.G., 1988, Plate tectonics and island arcs: Geological Society of America Bulletin, v. 100, p. 1503-1527.

Harding, T.P., Vierbuchen, R.C., and Christie-Blick, N., 1985, Structural styles, platetectonic settings, and hydrocarbon traps of divergent (transtensional) wrench faults, in Biddle, K.T., and Christie-Blick, N., eds., Strike-slip deformation, basin formation, and sedimentation: Society of Economic Paleotologists and Mineralogists Special Publication 37, p. 51-77. 
Hill, D.P., 1977, A model for earthquake swarms: Journal of Geophysical Research, v. 82, p. 1347-1352.

Hodgson, C.J., 1993, Measothermal lode-gold deposits, in Kirkham, R.V., Sinclair, W.D., Thorpe, R.I., and Duke, J.M., eds., Mineral deposit modeling: Geological Association of Canada, Special Paper 40, p. 635-678.

Hoffman, P.F., 1990, On accretion of grantite-greenstone terranes: NUNA Conference on Greenstone Gold and Crustal Evolution, Val d'Or, Canada, May 1990, p. 32-45.

Kerrich, R., and Wyman, D., 1990, Geodynamic settings of mesothermal gold deposits: An association with accretionary tectonic regimes, Geology, v. 18, p. 882-885.

Kerrich, R., and Feng, R., 1992, Archean geodynamics and the Abitibi-Pontiac collision- Implications for advection of fluids at transpressive collisional boundaries and the origin of giant quartz veins systems: Earth-Science Reviews, v. 32, p. 33-60.

Le Pichon, X., Angelier, J., and Sibuet, J.C., 1982, Plate boundaries and extensional tectonics, Tectonophysics, v. 81, p. 239-256.

Lindgren, W., 1895, Characteristics features of California gold-quartz veins: Geological Society of America Bulletin, v. 6, p 221-240.

Loucks, R.R., and Mavrogenes, J.A., 1999, Gold solubility in supercritical hydrothermal brines measured in synthetic fluid inclusions: Science, v. 284, p. 2159-2163.

MacDonald, A.J., 1984, Gold mineralization in Ontario: The role of banded iron formation, Canadian Institute of Mining and Metallurgy Special Volume 34, p 412-430.

Pettke, T, Diamond L.W., and Villa, I.M., 1999, Mesothermal gold veins and metamorphic devolatilization in the northwestern Alps-The temporal link: Geology, v. 27, no. 7, p. 641-644.

Phillips, N., and Zhou, T., 1999, Gold-only deposits and Archean granite: SEG Newsletter, no. 37, p. 1-8.

Robert, F., 1990, An overview of gold deposits in the Eastern Abitibi Subprovince, in Rouyn-Noranda 1990 Symposium, May 28-June 1, 1990, Proceedings: Canadian Institute of Mining and Metallurgy, Special Volume 43, p. 93-105.

Schubert, C., 1980, Late Cenozoic pull-apart basins, Bocono Fault Zone, Venezuelan Andes: Journal of Structural Geology, v. 2, p. 463-468.

Sibson, R.H., 1986, Earthquakes and lineament infrastructure: Transactions of the Royal Philosophical Society of London A-317, p. 63-79. 
Sibson, R.H., 1987, Earthquake rupturing as a mineralizing agent in hydrothermal systems: Geology, v. 15. P.701-704.

Wyman, D., and Kerrich, R., 1988, Archean lamprophyres, gold depositsa and transcrustal strtuctures: Implications for greenstone belt gold metallogeny: Economic Geology, v. 83, p. 454-459. 